\title{
Can dietary strategies in early life prevent childhood food allergy? A report from two iFAAM workshops
}

Roberts, G.; Grimshaw, K.; Beyer, K. Kirsten; Boyle, R.; Lack, G.; Austin, M.; Garcia-Larsen, V.; Grabenhenrich, L.; Halken, S.; Keil, T.

Total number of authors:

16

Published in:

Clinical and Experimental Allergy

Link to article, DOI:

10.1111/cea.13515

Publication date:

2019

Document Version

Peer reviewed version

Link back to DTU Orbit

Citation (APA):

Roberts, G., Grimshaw, K., Beyer, K. K., Boyle, R., Lack, G., Austin, M., Garcia-Larsen, V., Grabenhenrich, L. Halken, S., Keil, T., Bernhard Madsen, C., Regent, L., Schnadt, S., Szajewska, H., van Ree, R., \& Mills, E. N. C. (2019). Can dietary strategies in early life prevent childhood food allergy? A report from two iFAAM workshops. Clinical and Experimental Allergy, 49(12), 1567-1577. https://doi.org/10.1111/cea.13515

\section{General rights}

Copyright and moral rights for the publications made accessible in the public portal are retained by the authors and/or other copyright owners and it is a condition of accessing publications that users recognise and abide by the legal requirements associated with these rights.

- Users may download and print one copy of any publication from the public portal for the purpose of private study or research.

- You may not further distribute the material or use it for any profit-making activity or commercial gain

- You may freely distribute the URL identifying the publication in the public portal 
PROFESSOR GRAHAM ROBERTS (Orcid ID : 0000-0003-2252-1248)

DR KATE GRIMSHAW (Orcid ID : 0000-0003-3649-7963)

DR VANESSA GARCIA-LARSEN (Orcid ID : 0000-0002-0003-1988)

PROFESSOR HANIA SZAJEWSKA (Orcid ID : 0000-0002-4596-2874)

DR RONALD VAN REE (Orcid ID : 0000-0003-0767-0894)

Article type : Original Article-Epidemiology of Allergic Disease

\section{Can dietary strategies in early life prevent childhood food allergy? A report from two} iFAAM workshops

Roberts $\mathrm{G}^{1,2,3^{*}}$, Grimshaw $\mathrm{K}^{1,4^{*}}$, Kirsten Beyer $\mathrm{K}^{5}$, Boyle $\mathrm{R}^{6}$, Lack $\mathrm{G}^{7}$, Austin $\mathrm{M}^{8}$, Garcia-Larsen $V^{9}$, Grabenhenrich $L^{10}$, Halken $S^{11}$, Keil $T^{10}$, Madsen $C^{12}$, Regent $L^{8}$, Schnadt $S^{13}$, Szajewska $\mathrm{H}^{14}$, van Ree $\mathrm{R}^{15}$, Mills ENC ${ }^{16}$

${ }^{*}$ Equal contribution

\section{Affiliations:}

1. University of Southampton Faculty of Medicine, Southampton, UK

2. NIHR Southampton Biomedical Research Centre, University Hospital Southampton NHS Foundation Trust, Southampton, UK

This article has been accepted for publication and undergone full peer review but has not been through the copyediting, typesetting, pagination and proofreading process, which may lead to differences between this version and the Version of Record. Please cite this article as doi: 10.1111/CEA.13515

This article is protected by copyright. All rights reserved 
3. The David Hide Asthma and Allergy Research Centre, St Mary's Hospital, Isle of Wight, UK

4. Department of Dietetics, Salford Royal NHS Foundation Trust, Salford, UK

5. Department of Pediatric Pneumology and Immunology, Charite Universitatsmedizin, Berlin, Germany

6. Section of Paediatrics (Allergy and Infectious Diseases), Imperial College London, London, UK

7. King's College London, King's Health Partners, MRC \& Asthma UK Centre in Allergic Mechanisms of Asthma, and the Department of Paediatric Allergy, Guy's and St Thomas' NHS Foundation Trust, London, UK

8. The Anaphylaxis Campaign, Farnborough, UK

9. John Hopkins Bloomberg School of Public Health, Baltimore, USA

10. Institute for Social Medicine, Epidemiology and Health Economics, Charite Universitatsmedizin Berlin, Berlin, Germany

11. Hans Christian Andersen Children's Hospital, Odense University Hospital, Odense, Denmark

12. Technical University of Denmark, Lyngby, Denmark

13. German Allergy and Asthma Association, Mönchengladbach, Germany

14. Department of Paediatrics, The Medical University of Warsaw, Warsaw, Poland

15. Departments of Experimental Immunology and of Otorhinolaryngology, Academic Medical Center, University of Amsterdam, Amsterdam, The Netherlands

16. Institute of Inflammation and Repair, University of Manchester, UK

\section{Address for correspondence:}

Professor Graham Roberts, Paediatric Allergy and Respiratory Medicine, Mailpoint 803, Level F, South Academic Block, Southampton General Hospital, Tremona Road, Southampton SO16 6YD, UK; g.c.roberts@soton.ac.uk

\section{Word count: 4397}

Key words: diet, food allergy, nutrition, prevention 


\section{Abstract}

Food allergy affects a small but significant number of children and adults. Food allergy is responsible for considerable morbidity and is the commonest cause of anaphylaxis in children. One of the aims of the European Union funded "Integrated Approaches to Food Allergen and Allergy Risk Management" (iFAAM) project was to improve our understanding of the best way to prevent the development of food allergy. Groups within the project worked on integrating the current prevention evidence base as well as generating new data to move our understanding forward. This paper from the iFAAM project is a unique addition to the literature on this topic as it not only outlines the recently published randomised controlled trials (as have previous reviews) but it also summarises two iFAAM-associated project workshops. These workshops focused on how we may be able to use dietary strategies in early life to prevent the development of food allergy and summarises the range of opinions amongst experts in this controversial area.

\section{Introduction}

Food allergy represents a considerable burden to affected individuals. Around $5 \%$ of preschool children and between $0.3-5.6 \%$ of older children and adults in Europe have food allergy (1-5). Typical causative allergens are hen's egg, cow's milk, peanuts, tree nuts, wheat, soya, shell fish and fish (1,2). Food allergy is the commonest cause of anaphylaxis (6), a systematic and potentially life-threatening systemic allergic reaction (7). Current management strategies for food allergy revolve around avoidance of the causative allergen and rescue therapy for reactions (7). Avoidance of foods that are often a ubiquitous part of our diet is challenging, resulting in inconvenience to the individual and their family. Inconvenience also results from the need to carry rescue therapy, such as adrenaline auto-injectors. Although with adequate avoidance strategies, allergic reactions are infrequent, food allergy can result in considerable anxiety mainly due to their unpredictability (8).Therefore food allergy represents a considerable burden to individuals, families and society.

In the past, the prevailing hypothesis to explain the aetiology of food allergy was that early ingestion of allergenic foods would result in the development of food allergy in at risk individuals. The widely accepted approach to reducing the likelihood of an infant developing food allergy was therefore to delay the introduction of dietary allergens into their diet (9-11). The failure of these 
avoidance strategies to reduce the incidence of food allergy has led to a reassessment and the formulation of the dual exposure hypothesis (12). This reassessment developed from a number of different lines of evidence and suggests that initial contact of an allergenic food via the gastrointestinal tract in early life leads to development of tolerance; this contrasts with when initial contact is via eczematous skin when allergic hypersensitivity is likely to develop. This new hypothesis has led to a number of randomised controlled trials to assess whether the dietary introduction of allergens at 4-6 months leads to a reduction in the development of clinical food allergy. A number of these trials have now reported.

Integrated Approaches to Food Allergen and Allergy Risk Management (iFAAM) was an European Union funded FP7 project. iFAAM aimed to reduce the burden of food allergy through a number of integrated activities. The project evaluated the evidence relating to the development of food allergy to improve our approach to the prevention of food allergy. This paper is a summary from two iFAAM workshops held on $12^{\text {th }}$ December 2016 and $19^{\text {th }}$ to $20^{\text {th }}$ April 2018. The aims of these workshops were to review the recent key data on the prevention of food allergy; to make recommendations on the best approach to utilise infant diet to prevent food allergy; and consider what gaps remain in the evidence base. The discussion was focused on the introduction of complementary solid foods into the infant diet with "early" defined as less than 26 weeks of life. Participants were all involved in iFAAM and represented the breadth of stakeholders and range of opinions in this area for example paediatricians, dietitians, patient group representatives, and food scientists.

\section{Potential impact of altering the age of introduction of allergenic solids on infant nutrition}

In making recommendations about infant diet, a holistic view is required, as positive impacts in one clinical area may need to be balanced with negative ones in another. This can be seen by the effect of feeding recommendations on the overall composition of the infant diet. Historically infants were breast fed for their first year of life with solids introduced once they were able to physically eat, e.g. being able to hold head up independently. Initiation rates and duration of breast feeding started to decline in many European Countries in the 1950s (Figure 1). At that time, complementary foods could be started from as early as 6-8 weeks of age. From the 1970s there were recommendations to introduce complementary foods later $(13,14)$. In 2003, the World Health Organisation recommended exclusive breastfeeding until 26 weeks of age with continued breastfeeding until two years of age (15). In practice, this is rarely achieved in many countries in the developed world (8). Where breastfeeding is not prolonged, delaying the introduction of 
complementary foods means that there is less or even no overlap between breast feeding and the introduction of solids and this may have a detrimental effect on allergy development (11). Additionally, guidelines may be directed at particular population groups (e.g. high risk infants) but are followed by all population groups $(9,10)$.

The format in which a food is eaten is very important for infants and is affected by their age. Consequently this needs to be considered when deciding how to introduce allergenic foods into the diet. For example, egg is traditionally introduced into an infant's diet in a well-cooked format to overcome texture issues and is consequently given at a relatively low dose. This observation is supported by available trial data which demonstrates that cooked egg is much better tolerated than raw egg and is consumed in lower doses (16). Likewise, the choking risk with peanuts also needs to be considered, children under 5 years of age should only consume these in a ground/smooth format such as peanut butter or satay sauce. Consideration is also needed to ensure that any recommended changes to the infant diet are in line with local dietary practice. For example, peanuts are not part of the local diet in many areas of the world. Finally, the impact of any recommendations requires reflection to ensure it has no negative nutritional or dietary consequences. For example, peanuts formulated as peanut puffs have a relatively high sodium chloride and fat content and nutritional data from the LEAP study showed that the early introduction did have a major impact on the relative intake of key nutrients, although no adverse effects on growth were found (17). Peanut would be better introduced as part of the protein content of meals rather than as a snack to reduce the potential for an infant having too much protein, protein-associated fat and sodium chloride in their diet which have long-term health consequences including obesity in later life (18). Finally, there is a need to look for potential longterm consequences as our dietary experience as infants affects our long-term diet and therefore health (19).

All these factors demonstrate why it is important that one clinical speciality should not drive public nutrition recommendations. The European Society of Paediatric Gastroenterology and Nutrition have published updated recommendations on complementary feeding (20). They recommended that "exclusive or full breast-feeding should be promoted for at least 4 months and exclusive or predominant breast-feeding for approximately 6 months is a desirable goal." Additionally they recommend that "complementary foods should not be introduced before 4 months but should not be delayed beyond 6 months." They explain that they base these recommendations on when an infant has the necessary maturity in gastrointestinal, renal and motor function to safely consume complementary foods.

This article is protected by copyright. All rights reserved 
Figure 1. Illustration of the historic trends in breasting feeding and the introduction of allergenic solids into the infant diet in the UK

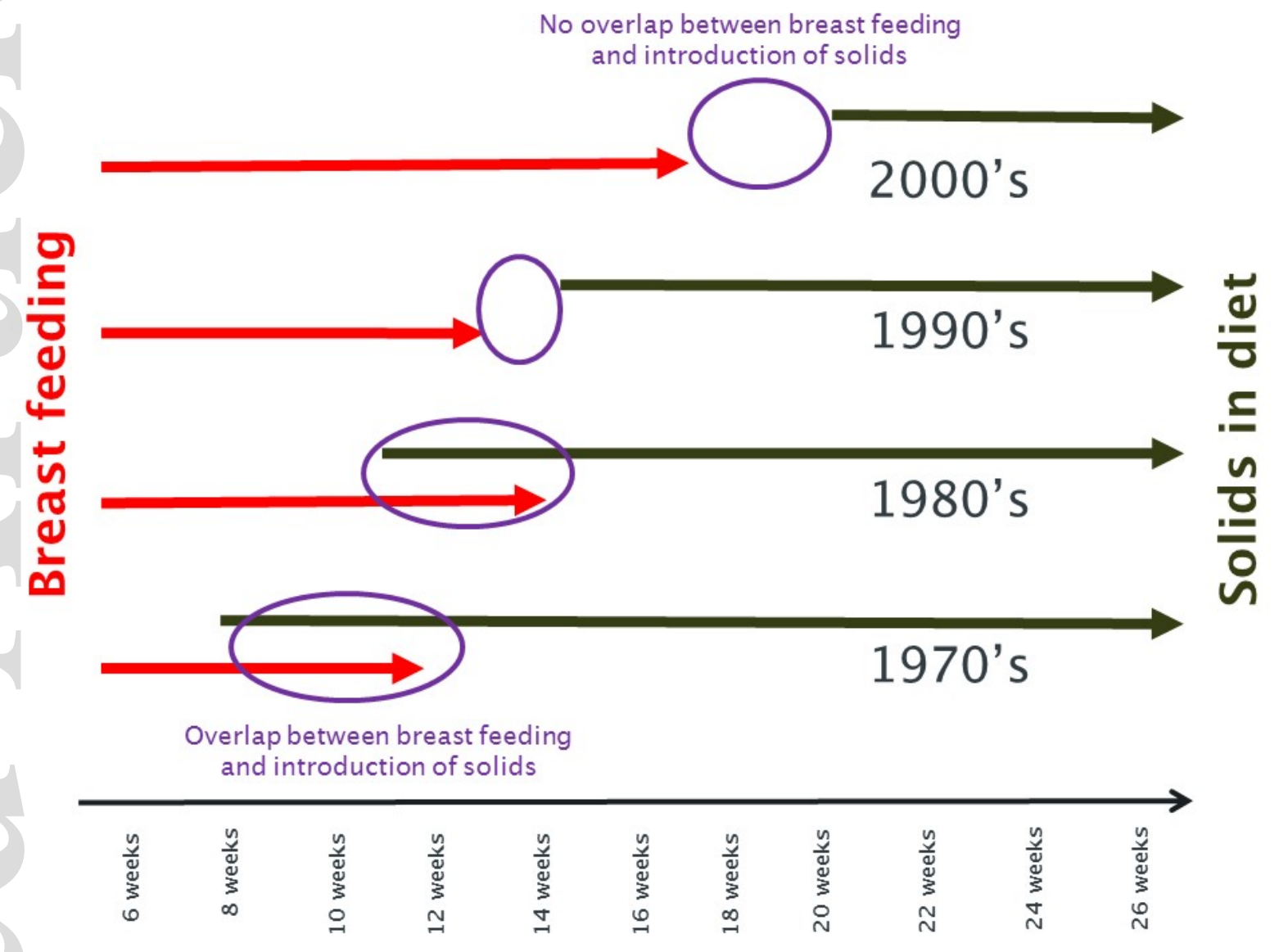

Figure illustrates the typical timelines for breast feeding and the introduction of solids into the infant diet in the last 4 decades in the UK where the LEAP and EAT were undertaken $(13,14,21-23)$. However, an overlap between breastfeeding and the introduction of solids can still be seen in other European countries such as Norway and Denmark (24).

\section{Randomised controlled prevention trials focused on early introduction of allergenic solids}

A literature search was undertaken in Medline and EMBASE ([food allergy or hypersensitivity or intolerance] and [prevention] and [SIGN randomised controlled trial search strategy (25)]). Additionally, Clinicaltrials.gov, www.clinicaltrialsregister.eu, www.controlled-trials.com, and http://www.anzctr.org.au were searched for ongoing or planned randomised controlled trials $\left(18^{\text {th }}\right.$ April 2018) and re-run for any new studies $7^{\text {th }}$ December 2019. A total of 7 randomised studies 
focusing on the question of whether the early introduction of allergenic solids might prevent the development of food allergy have been published; a further one is ongoing (Table 1). Most of the studies focus on egg $(16,26-29)$, one has focused on peanuts $(30,31)$ and one on multiple foods (32). One trial of multiple food allergies (PreventADALL) is still ongoing (33). Lastly, there is one non randomised trial on peanut allergy in high risk infants (PEAP) that is also ongoing (34). To understand these studies fully, a number of different aspects need to be understood:

Population - studies have focused on either a high risk group $(16,26,30,31)$, moderate risk $(27,28)$ or a general population $(29,32,33$. High risk has been defined as the presence of moderate to severe eczema, which is known to be associated with food allergy (35). Moderate risk has been defined as a first degree relative with allergy $(27,28)$. Some studies have aimed to recruit a general population although inevitably, those enrolled are likely to be more at risk than a truly representative general population $(29,32,33)$. Studies based in an at risk population have a better chance of identifying any preventative impact of an intervention as more individuals develop food allergy than in the general population. There is though a possibility that such high risk infants have already developed food allergy. The successful impact of the LEAP intervention in sensitised infants (SPT $<4 \mathrm{~mm}$ ) would argue against this at least for peanut allergy. In the STAR study (26), which did not screen for sensitisation prior to inclusion in the study, many infants reacted to the egg intervention and these infants had significantly higher SplgE to egg at recruitment than those who did not react. However in the HEAP (study (29) only infants who were not sensitised were included and there were still frequent reactions to the egg intervention.; this was not seen in the PETIT study (16) who did not screen by Egg specific IgE prior to inclusion. The likely explanation for this difference was the use of small doses of heated hen's egg in the PETIT study.

Intervention - foods have been introduced in a number of formats and doses. For the egg interventions, a number of studies used a format that appears to be similar to raw egg in terms of allergenicity $(16,27-29)$. But the EAT and PETIT studies used a cooked form of egg $(16,32)$. Interestingly, it appears introduction of the "raw" egg into the infant diet does not prevent the development of egg allergy and results in lots of allergic side effects. Meanwhile, introduction of the cooked form into the infant diet possibly results in a reduction in the development of egg allergy and has been well tolerated. One challenge here though is that it is difficult to standardise the degree of cooking. Other factors may also be important, for example the matrix (Table 2). Dose wise, studies have used a wide range of amount of food. Most of the egg studies have used an amount equivalent to approximately $1 / 2-1$ egg per week $(26-29,32)$. The exception is the PETIT study, which started with a low daily egg protein intake (equivalent to $1 / 20$ th of an egg a week) 
from 6- 9 months, followed by daily intake equivalent to a $1 / 4$ of an egg a week from 10-12 months and was associated with a very large reduction in egg allergy (16). It is important to note that the hen's egg in the PETIT and EAT study was well cooked. For the peanut studies, the LEAP study gave $6 \mathrm{~g}$ peanut protein per week $(30,31)$ whereas the EAT study used $4 \mathrm{~g}$ of peanut protein $(32)$.

Timing of introduction of allergen solid(s) - the egg studies have all introduced this allergen at 4-6 months of age (22-26) while the peanut study introduced the allergen from 4-11 months (mean 7.8 months) $(27,28)$. In the EAT study, allergenic foods were introduced between 4-6 months except for cow's milk which was introduced from 3 months (29).

Comparator - only some of the studies had a double-blind design (26-29); the other randomised controlled trials were open in design (26-28). Without blinding there is a potential for reporting bias; to overcome this, the primary outcome needs to be objective and robust. The success of the randomisation also needs to be examined, for example, there was an imbalance in baseline sensitisation to egg in the PETIT study although a post hoc analysis did suggest that this did not affect the result (16).

Outcomes - the patient relevant outcome is food allergy which is assessed in most studies (2632 ) only some used a double-blinded challenge protocol $(25,26-28)$. Challenge results can be difficult to define accurately in small infants. Several studies have used sensitisation as their primary outcome $(28,29)$; given the data that sensitised infants can be protected from developing food allergy $(30,31)$, it is difficult to know how to interpret these sensitisation results in isolation from accompanying challenge results.

This article is protected by copyright. All rights reserved 
Table 1. Summary of randomised controlled studies investigating the impact of early introduction of allergenic foods on prevention of food allergy

\begin{tabular}{|c|c|c|c|c|}
\hline Name of Trial & $\begin{array}{l}\text { Country } \\
\text { (institution) }\end{array}$ & Population & Study details & Results \\
\hline \multicolumn{5}{|l|}{ Egg } \\
\hline $\begin{array}{l}\text { Hens' Egg Allergy } \\
\text { Prevention } \\
\text { (HEAP) } \\
\text { Bellach et al } \\
\text { (29) }\end{array}$ & $\begin{array}{l}\text { Germany } \\
\text { (Charité } \\
\text { Universitätsme } \\
\text { dizin Berlin, } \\
\text { Germany) }\end{array}$ & $\begin{array}{l}\text { General } \\
\text { population, non- } \\
\text { sensitised } \\
\text { (Screened at } \\
\text { recruitment) }\end{array}$ & $\begin{array}{l}\text { - RCT, placebo controlled } \\
\text { - } \mathrm{n}=383 \\
\text { - Enrolled at } 4-6 \text { months then consumption of egg powder } \\
\text { ("pasteurized egg white" equal in its allergenicity to raw } \\
\text { hen's egg) or placebo until } 12 \text { months of age; started with } \\
800 \mathrm{mg} \text { egg protein three times a week, increasing to } 1.6 \mathrm{~g} \\
\text { in week } 2 \text { and } 2.5 \mathrm{~g} \text { in week } 3 \text {. } \\
\text { - Outcome: primary: prevalence of egg sensitisation; } \\
\text { secondary: placebo controlled challenge proven IgE- } \\
\text { mediated egg allergy at } 12 \text { months of age }\end{array}$ & $\begin{array}{l}\text { At } 12 \text { months there was a non- } \\
\text { significant difference in egg } \\
\text { sensitisation ( } 2.6 \% \text { control vs } 5.6 \% \text { egg, } \\
p=0.24) \text { and egg allergy }(0.6 \% \text { control vs } \\
2.1 \% \text { egg, } p=0.35) \text { between the groups } \\
\text { in ITT analyses; many infants reacted to } \\
\text { the intervention. }\end{array}$ \\
\hline $\begin{array}{l}\text { Prevention of } \\
\text { egg allergy in } \\
\text { infants with } \\
\text { atopic } \\
\text { dermatitis } \\
\text { (PETIT) }\end{array}$ & $\begin{array}{l}\text { Japan } \\
\text { (National } \\
\text { Centre for } \\
\text { Child Health } \\
\text { and } \\
\text { Development, }\end{array}$ & $\begin{array}{l}\text { High risk (infants } \\
\text { with atopic } \\
\text { dermatitis) }\end{array}$ & $\begin{array}{l}\text { - RCT, placebo controlled } \\
\text { - } \mathrm{N}=147 \\
\text { - Enrolled at } 4-6 \text { months then consumption of "heated egg } \\
\text { powder" or placebo; started on a very small amount ( } 25 \\
\text { mg of egg protein daily increasing to } 125 \mathrm{mg} \text { from } 9 \\
\text { months) } \\
\text { - Outcome: prevalence of open challenge proven IgE }\end{array}$ & $\begin{array}{l}\text { Recruited finished early after an interim } \\
\text { analysis; intervention lead to a } \\
\text { significant reduction in egg allergy ( } 38 \% \\
\text { control vs } 8 \% \text { egg, } p=0.0001) \text {; no major } \\
\text { safety issues. }\end{array}$ \\
\hline
\end{tabular}

This article is protected by copyright. All rights reserved 


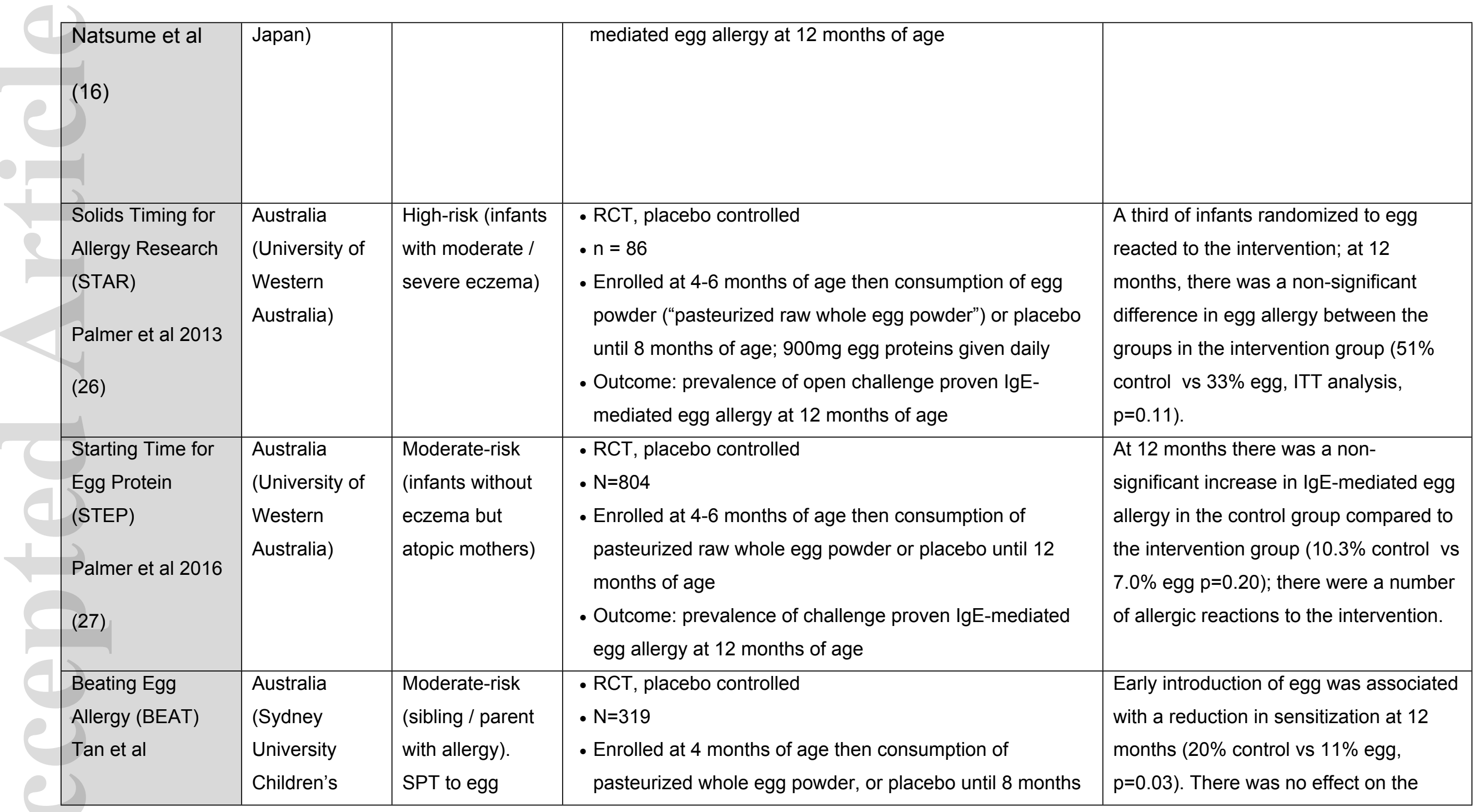

This article is protected by copyright. All rights reserved 


\begin{tabular}{|c|c|c|c|c|}
\hline (28) & Hospital) & $<2 \mathrm{~mm}$ & $\begin{array}{l}\text { of age } \\
\text { - Outcome: primary egg white sensitisation; secondary: } \\
\text { prevalence of IgE mediated egg allergy at } 12 \text { months of } \\
\text { age }\end{array}$ & $\begin{array}{l}\text { proportion of children with probable egg } \\
\text { allergy. A number of infants reacted to } \\
\text { the intervention. }\end{array}$ \\
\hline Peanut & & & & \\
\hline $\begin{array}{l}\text { Learning Early } \\
\text { About Peanut } \\
\text { allergy (LEAP) } \\
\text { Du Toit et al } \\
(30,31)\end{array}$ & $\begin{array}{l}\text { UK (Kings } \\
\text { College, } \\
\text { London) }\end{array}$ & $\begin{array}{l}\text { High-risk (infants } \\
\text { with moderate / } \\
\text { severe eczema } \\
\text { and / or egg } \\
\text { allergy). SPT to } \\
\text { peanut < } 4 \mathrm{~mm}\end{array}$ & $\begin{array}{l}\text { - Open-label RCT } \\
\text { - } \mathrm{n}=640 \\
\text { - Enrolled at } 4-11 \text { months (mean age } 7.8 \text { months) then } \\
\text { peanut consumption or avoidance until age } 5 ; 6 \mathrm{~g} \text { peanut } \\
\text { protein per week } \\
\text { - Outcome: prevalence of DBPCFC confirmed peanut } \\
\text { allergy at } 5 \text { years of age }\end{array}$ & $\begin{array}{l}\text { Significant reduction at } 60 \text { months in ITT } \\
\text { analysis ( } 13.7 \% \text { control vs } 1.9 \% \text { overall, } \\
p<0.001 \text { ) regardless of presence of } \\
\text { initial (cutaneous) sensitisation; no } \\
\text { significant between-group differences in } \\
\text { serious adverse events. Significant } \\
\text { reduction still seen after both groups } \\
\text { then avoided peanut for a year ( } 18.6 \% \\
\text { control vs } 4.8 \% \text { peanut, ITT analysis, } \\
p<0.001 \text { ). }\end{array}$ \\
\hline Multiple foods & & & & \\
\hline $\begin{array}{l}\text { Enquiring About } \\
\text { Tolerance (EAT) } \\
\text { Perkin et al } \\
\text { (32) }\end{array}$ & $\begin{array}{l}\text { UK (Kings } \\
\text { College, } \\
\text { London) }\end{array}$ & $\begin{array}{l}\text { General } \\
\text { population }\end{array}$ & $\begin{array}{l}\text { - Cows' milk, hens' egg, peanut, cod, sesame, wheat } \\
\text { - Open-label RCT } \\
\text { - } \mathrm{n}=1106 \\
\text { - Enrolled at } 3 \text { months of age then consumption of } 6 \\
\text { allergenic foods until } 6 \text { months or exclusive breastfeeding } \\
\text { until } 6 \text { months of age; } 2 \mathrm{~g} \text { protein of each food given twice } \\
\text { a week }\end{array}$ & $\begin{array}{l}\text { Non-significant reduction in ITT analysis } \\
(7.1 \% \text { control vs } 5.6 \% \text { intervention, } \\
p=0.32) \text {. In PP analysis, a significant } \\
\text { reduction was seen for any food allergy } \\
(7.3 \% \text { control vs } 2.4 \% \text { intervention, } \\
p=0.01) \text {, peanut }(2.5 \% \text { control vs } 0 \% \\
\text { peanut, } p=0.003) \text { and egg allergy }(5.5 \%\end{array}$ \\
\hline
\end{tabular}

This article is protected by copyright. All rights reserved 


\begin{tabular}{|c|c|c|c|c|}
\hline 7 & & & $\begin{array}{l}\text { - Outcome: prevalence of IgE-mediated food allergy to any } \\
\text { of the } 6 \text { allergenic foods between } 1 \text { and } 3 \text { years of age }\end{array}$ & control vs $1.4 \%$ egg, $p=0.009)$ \\
\hline $\begin{array}{l}\text { Preventing atopic } \\
\text { dermatitis and } \\
\text { allergies in } \\
\text { children } \\
\text { (PreventADALL) } \\
\text { (33) }\end{array}$ & $\begin{array}{l}\text { Norway (Oslo } \\
\text { University } \\
\text { Hospital) }\end{array}$ & $\begin{array}{l}\text { General } \\
\text { population }\end{array}$ & $\begin{array}{l}\text { - Hen's egg, milk, wheat, peanut } \\
\text { - Open label RCT with four arms: observation, early } \\
\text { introduction by } 4 \text { months, skin care, both early introduction } \\
\text { and skin care } \\
\text { - } \mathrm{N}=2500 \\
\text { - Outcome: food allergy, atopic dermatitis }\end{array}$ & Ongoing \\
\hline
\end{tabular}

DBPCFC, double blind, placebo controlled food challenge; ITT, intention to treat; PP, per protocol; RCT, randomised controlled trial.

This article is protected by copyright. All rights reserved 


\section{Synthesis of the randomised control prevention trials}

A systematic review and meta-analysis of these randomised controlled prevention trials has been published (36). Level of risk for developing food allergy differed between these populations and can be seen in Table 1. An updated figure from the review is reproduced as Figure 2. The analyses suggest that the early introduction of peanut and egg are effective in preventing the development of peanut and egg allergy respectively. The PETIT study is a cause of much of the heterogeneity (16), and it has been criticised given that it was stopped early, after an interim analysis, when the two groups were unbalanced for the presence of specific lgE to egg (36). However, meta-analysis of the egg studies remains positive for a preventative effect even if the PETIT study is removed from the analysis. These updated data give a number needed to treat to prevent egg and peanut allergy of 28 and 18 respectively. The analysis for milk allergy failed to demonstrate that early introduction is an effective preventative strategy.

\section{Figure 2. Meta-analysis of randomised controlled prevention studies}

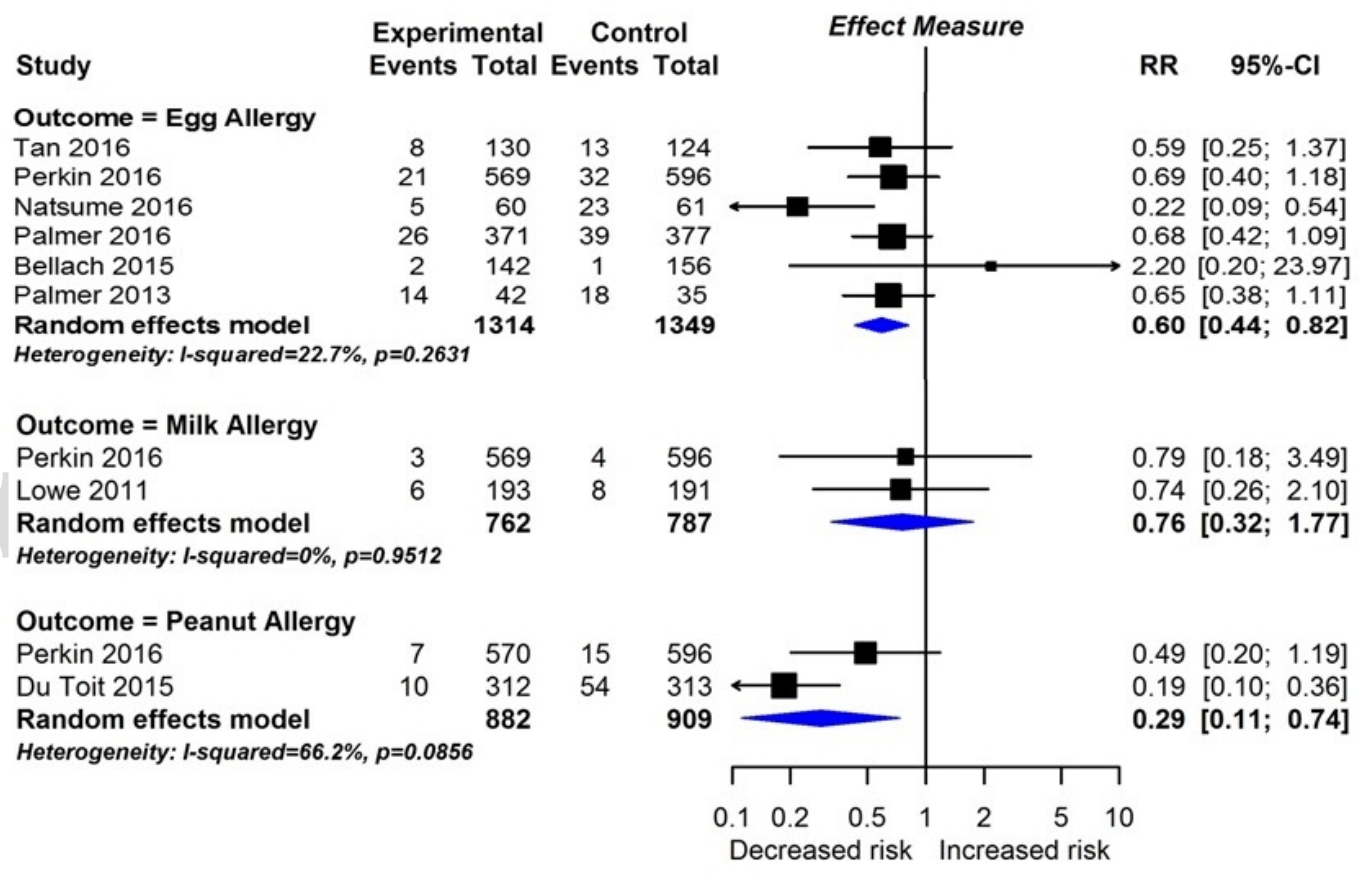

Updated from lerodiakonou et al (36) where results for egg, milk and peanut allergy are presented separately. Error bars represent $95 \%$ confidence intervals. 
A subsequent systematic review and meta-analysis of studies looking at early introduction of egg and allergy development indicated that neither the total amount nor pre-treatment of egg showed any effect on egg allergy development at the age of 12 months. The authors propose further studies should be performed to generate stronger data (35).

\section{Interpretation of the randomised controlled prevention trial data}

For egg, milk and peanut, there are important limitations in the currently available data. There is heterogeneity in both the egg and peanut analyses. For egg, this is largely explained by the imbalance in risk factors for egg allergy at baseline in the PETIT study, the early termination of recruitment in this trial and the usage of very different amounts of the allergen (16). For peanut the heterogeneity may be explained by very different adherence to the intervention seen in the LEAP and EAT studies and also the different population groups (Table 1) (30-32). The data for peanut allergy is based on two studies from one institution and it remains to be seen whether the findings are generalizable to other countries with different breastfeeding initiation rates and durations, different prevalences of eczema and different household peanut consumption. Peanut allergy is also not seen in many countries. We do not have data for other allergenic foods. Lastly, we need to consider the potential for adverse consequences of the early introduction of allergenic solids; this is discussed in the next section.

So while there appears to be a proof of concept that early introduction of allergenic solids in the right amounts, in the right formulation and at the right time can reduce the development of food allergy in infants, important gaps in the evidence base remain (Table 2). The heterogeneity of the published studies is a particular concern with differences in the included populations, format and dose of the intervention and how "early" was defined. This heterogeneity could be used to optimise the approach but a definitive study would then be required to assess this strategy.

\section{Can we extrapolate from the available evidence to other food groups?}

Allergic reactions to different foods present very differently. Although their presentation is usually temporally associated with when that food group first appears in the diet, it is possible that clinically relevant allergy develops sometime before the first known ingestion. This may be different for different foods. For example, trials have demonstrated that peanut interventions are well tolerated even by sensitised infants up to 11 months of age (30-32) whereas many younger infants have allergic reactions with the raw pasteurised egg intervention $(26,29)$. However, this 
difference may just as easily be due to the form the foods were ingested and how the infants were screened prior to inclusion in the study.

Additionally, there may be different "windows of opportunity" for prevention to different allergenic foods during childhood. Also, whether or not the allergy is outgrown and the speed that this happens is very variable making extrapolation to other foods problematic. However, the mechanisms that underlie tolerance are likely to be similar for all foods and will involve either clonal deletion, clonal anergy, or suppression. At present we can only compare early introduction of different foods in the EAT study (32) and this was underpowered to look individually at the less prevalent food allergies. We need more evidence for all the food groups (Table 2).

\section{Is there adequate evidence to make recommendations about the best approach for solid introduction and allergy prevention?}

Participants at the first workshop (2016) were asked to consider, in four small groups, whether there was sufficient current evidence to make recommendations about the age of introduction of complementary solids into the infant diet to reduce the likelihood of developing food allergy. In the second workshop, groups were asked to consider i) the definition of a high risk infant; ii) when foods should be introduced to low risk infants; iii) when foods should be introduced to high risk infants; iv) what are the potential consequences of early introduction of allergenic foods; v) should different foods be introduced at different ages and vii) in what format should foods be introduced.

There was agreement by participants at the 2018 workshop that there is a paucity of evidence to be able to define absolutely high(er) risk populations for the development of food allergy. However, it was thought that whilst a family history of allergies is widely acknowledged to increase the risk of food allergy development, there are other factors such as early onset eczema, ethnicity and geography that also have an effect and need to be considered.

All the participants at the first workshop (2016) agreed that breastfeeding should be recommended until at least 6 months of age, not based on its impact on food allergy but due to its other proven health benefits. The most recent systematic review on this topic compared maternal and infant outcomes with exclusive breastfeeding for 6 months versus 3 to 4 months (38). A total of 23 eligible studies (11 from low- and 12 from high-income countries) were included. Some benefits for exclusive breastfeeding for 6 months were seen, for example reduced gastrointestinal infection even in high-income countries. A weakness of the evidence base is that most of the studies are observational with no randomised controlled trials in high-income countries. Moreover 
exclusive breastfeeding duration in these studies was often determined by the introduction of breastmilk substitutes rather than introduction of solids, and it is unclear whether early introduction of solid foods on its own increases risk for gastrointestinal infection. At the second workshop (2018) the question of breastfeeding duration for allergy protection was not discussed directly but continuing to breastfeed whilst introducing solids into the diet was recommended by the many participants when answering the other questions (detailed above).

In 2016, all the discussion groups discussed when the allergenic foods should be introduced into the infant diet. For egg, most thought that it could be introduced into the diet of all infants from 4-6 months of age, when they are developmentally ready. Given the trial evidence, it was agreed that this should probably be in small amounts of the well-cooked or baked form that is appropriate within the local diet. However one group believed that the heterogeneity in the design of the completed trials and the relatively high number of adverse reactions meant that firm conclusions could not be made. Pragmatically this results in a timeframe around 4-6 months of age. The lack of consensus between the workshop participants indicated the need for additional data focused on the format and dosage of egg used in the intervention (Table 2). Since the first workshop there have been two international consensus documents have made recommendations for egg. The Asia Pacific Association of Pediatric Allergy, Respirology \& Immunology (APAPARI) consensus statement says that high risk infants with severe eczema should first be assessed by an allergy specialist if parents want to introduce egg from 5-6 months of age (39). Meanwhile the Australian Society of Clinical Immunology and Allergy (ASCIA) states "all infants should be given allergenic solid foods including peanut butter, cooked egg, dairy and wheat products in the first year of life" (40). The participants at the second workshop (2018) reached a consensus that egg should be introduced first in the heated or cooked form, after the establishment of weaning by the introduction of low allergenic foods, e.g. fruit and vegetables between 4-6 months of age.

For peanut there was no consensus in either of the discussion groups. One group thought that the peanuts should be introduced into the diet of infants in the general population from around 4 months based on the evidence of benefit from the LEAP study (30.31) and lack of evidence of harm in the EAT study (32). Another group believed that data from the LEAP and EAT studies (30-32) was sufficient to recommend introducing peanuts into the diet of infants with severe eczema and/or hens egg allergy from the age of 4-11 months after testing for sensitisation to peanut in the UK. They restricted their recommendation because of the selected population recruited into LEAP $(30,31)$, the lack of replication in the intention to treat analysis in the EAT study (32) and lack of evidence from outside of the UK. This is similar to the stance taken by an international consensus group (41), ESPGHAN (20), the Australian society $(40)$, BSACI $(42,43)$ 
and Asian association (where peanut prevalence is high) (39) although these extend their recommendations to all countries with a high prevalence of peanut allergy. The more recent US National Institute of Allergy and Infectious Diseases extend the recommendations of peanut introduction of around 6 months to infants at moderate and low risk of developing peanut allergy, however, only in accordance with family preferences and cultural practice (44). Other discussion groups agreed that peanut should be introduced into the infant diet once they are developmentally ready and other solids have been introduced; they thought that this would ideally be 4-6 months of age given the potential risk of increased risk of peanut allergy if introduction is delayed. The range of views clearly identify this is still a topic where there is a substantial gap in available evidence with the perceived need for confirmatory data from inside and outside the UK and in low risk infants (Table 2). Finally the US National Institute of Allergy and Infectious Diseases has suggested that in countries where peanut products are not widely consumed by adults, early dietary introduction of peanut could lead to an increase in sensitization and allergic manifestations (44). This fact was mentioned in the discussion at the 2018 workshop when answering the question of what potential adverse consequences of early introduction of allergenic foods. Other potential adverse consequences were given as allergic reactions (including anaphylaxis) and more rarely FPIES and EoE, increased risk of sensitisation, and the adverse impact on other eating patterns and nutritional intake.

For allergenic foods, the 2018 workshop reached consensus that allergenic foods should be introduced at around the same time as other complementary foods are introduced as per countryspecific recommendations and culinary and family practices. However, it was thought that there were insufficient data to make recommendations about when other allergenic foods should be introduced into the infant diet, a further gap in the evidence base (Table 2).

This article is protected by copyright. All rights reserved 
Table 2. Research gaps

Gap

Approach to closing gap

Priority

General considerations

Evidence that early

introduction of solids is

beneficial for low risk infants.
Needs very large randomised controlled trial in a low risk population and in different countries as current observational data are confounded by socioeconomic factors.

Randomised controlled trial but impact likely to be different for different foods so trials need to be powered to look at specific foods.

Secondary analysis of published trials to assess optimal format and dose. Further assessment of hypothesised optimal approach in a randomised controlled trial.

Further studies need to control for a potential matrix effect.

food processing and the food matrix may affect the

prevention of food allergy.

Potential role of maternal consumption and transfer of dietary protein to infant via breast milk on the prevention of food allergy

The longevity of any preventative impact.

Evidence that allergenic solid introduction with concurrent breast feeding is protective Short term nutritional safety of early introduction of
Ongoing follow up of randomised controlled trials. Before-after controlled trials. Need to examine in datasets of existing RCT studies, or to be examined in future studies.

Future trials need to control for or investigate the potential impact of maternal consumption of allergenic foods on the prevention of food allergy.

\section{Nutritional consequences of infant dietary} interventions need to be assessed. Need to 
allergenic solids.

Longterm safety of early introduction of allergenic solids, eg hypertension, obesity and diabetes

\section{Egg}

Best dose and format of egg. examine EAT (and other RCT) data sets

This requires longterm follow up of randomised $++$ controlled trial participants, potentially using routine health data. Alternatively, before-after controlled trial approach could be used.

Positive studies use a wide variety of doses and formats of egg, need a comparative randomised controlled trial to assess the best approach.

\section{Peanut}

Replication of LEAP data in Multi-centre randomised controlled trial building on LEAP study protocols.

other countries with a high,

moderate and low prevalence

of peanut allergy and

different cultural practices around infant feeding.

\section{Other foods}

Will the LEAP approach work for tree nuts?

Multi-centre randomised controlled trial building on LEAP study protocols.

Effective preventative Perhaps a clinical trial of early introduction of approach for cow's milk cow's milk alongside breast feeding.

allergy.

Lack of evidence about the best time to introduce other food allergens.

\section{Further randomised controlled trials.}

\section{Summary and future perspectives}


Over the last years, we have seen some initial attempts to assess the role of early allergen introduction on food allergy development with intervention trials. Data are now available for egg with some also for peanut and milk allergy. Delaying the introduction of egg or peanut to the infant diet also appears to increase their risk for egg or peanut allergy. This may be particularly relevant for infants at high risk for developing food allergy, such as those with early onset troublesome eczema.

The randomised controlled trial data suggest that the early introduction of egg into the infant diet might be associated with the development of less egg allergy. However, questions remain given the heterogeneity in the format and dosage of egg used in different studies plus many infants reacted to the intervention with sometimes life-threatening symptoms. The majority of participants in the workshop thought that there was sufficient evidence to recommend that cooked egg should be introduced into the diet of all infants from 4-6 months of age, when they are developmentally ready, to reduce the likelihood of egg allergy developing. However, others thought that the heterogeneity in trial designs and results precluded any preventative recommendations. A further large trial using a cooked form of egg is clearly required to resolve this.

There is clear evidence of benefit from the early introduction of peanut in one study but limited replication data and no data from outside of the UK. Although National and European government and academy organisations have used these data to make wide ranging recommendations, consensus was not achieved in either of the workshops. Many participants were concerned by the lack of replication data and the generalisability of the results. Given the potential for the early introduction of peanuts into the diet as being a very successful public health preventative strategy, there is an obviously an urgent need for a replication study in a more general risk population outside of the UK.

There are obvious gaps in the evidence base for other foods although foods such as tree nuts represent important causes of food allergy. We have still much to understand about how the infant diet can be modified to reduce the likelihood of developing food allergy. However, we do have the basis to plan and conduct the much needed further trials using the best methodological approach possible. We also need to understand any potential adverse nutritional consequences of altering the infant diet and any long-term impact, both positive and potentially negative, of such strategies.

There remains the challenge as to how to advise the families of infants who are at low, medium and high risk of developing food allergies. There was a consensus at the 2016 workshop that we should be advising that infants are breast fed for at least 6 months but not for any impact on food 
allergy. The 2018 workshop added that cooked egg can be introduced between 4-6 months of age and peanut may be introduced between 4-11 months if culturally appropriate. There are now international guidelines $(20,39-44)$ that recommend the early introduction of peanuts into the infant diet to prevent allergy in countries with a high prevalence of peanut allergy; but how this is achieved differs according the whether they are considered to be at high risk of developing food allergy. In alternative approach is to return to the situation where there in no deliberate delay of introducing any food to an infant but to introduce it when they are developmentally ready (rather than delaying introduction), this will usually be when they are 4-6 months of age.

\section{Acknowledgement}

This report was generated as part of the EU iFAAM project: Integrated Approaches to Food Allergen and Allergy Risk Management (Grant Agreement No 312147) and an iFAAM workshop held at the UK Food Standards Agency. We would like to acknowledge the assistance of the UK Food Standards Agency in hosting the workshop. Liz Kendall and Erin Oliver from the Food Standards Agency and Rachel Elsom from Public Health England were observers at the workshop. We would also like to acknowledge the support of ILSI in arranging the second workshop.

\section{References}

1. Nwaru BI, Hickstein L, Panesar SS, Roberts G, Muraro A, Sheikh A on behalf of The EAACI Food Allergy \& Anaphylaxis Guidelines Group. Prevalence of common food allergies in Europe: a systematic review and meta-analysis. Allergy 2014; 69: 992-1007.

2. Nwaru BI, Hickstein L, Panesar SS, Muraro A, Werfel T, Cardona V, et al. The epidemiology of food allergy in Europe: a systematic review and meta-analysis. Allergy 2014a; 69: 62-75.

3. Schoemaker AA, Sprikkelman AB, Grimshaw KE, Roberts G, Grabenhenrich L, Rosefeld L et al. Incidence and natural history of challenge-proven cows milk allergy in European childrenEuroPrevall birth cohort. Allergy 2015

4. Xepapadaki P, Fiocchi A, Grabenhenrich L, Roberts G, Grimshaw KEC, Fiandor A,et al. Incidence and natural history of hen's egg allergy in the first 2 years of life-the EuroPrevall birth cohort study. Allergy 2016; 71: 350-357. 
5. Lyons $S A^{1}$, Burney $P G J^{2}$, Ballmer-Weber $B K^{3}$, Fernandez-Rivas $M^{4}$, Barreales $L^{5}$, Clausen $M^{6}$, et al Food Allergy in Adults: Substantial Variation in Prevalence and Causative Foods Across Europe. J Allergy Clin Immunol Pract. 2019 Mar 19. pii: S2213-2198(19)30269-7. doi: 10.1016/j.jaip.2019.02.044

6. Panesar SS, Javad S, de Silva D, Nwaru BI, Hickstein L, Muraro A, et al. The epidemiology of anaphylaxis in Europe: a systematic review. Allergy 2013;68: 1353-1361.

7. Muraro A, Roberts G, Worm M, Bilò MB, Brockow K, Fernández Rivas M, et al. Anaphylaxis: Guidelines from the European Academy of Allergy and Clinical Immunology. Allergy 2014: 69: 1026-45.

8. Salvilla SA, Dubois AEJ, Flokstra-de Blok BMJ, Panesar SS, Worth A, Patel S, et al. Diseasespecific health-related quality of life (HRQL) instruments for IgE-mediated food allergy. Allergy 2014; 69: 834-844.

9. Committee on Toxicity of Chemicals in Food, Consumer Products and the Environment. Peanut allergy. 1998. https://cot.food.gov.uk/committee/committee-ontoxicity/cotreports/cotwgreports/cotpeanutallergy (last accessed 13th January 2019).

10. Ronald E. Kleinman. American Academy of Pediatrics Recommendations for Complementary Feeding. Pediatrics 2000;106;127.

11. Grimshaw K, Logan K, O'Donovan S, Kiely M, Patient K, van Bilsen J, Beyer K, Campbell DE, Garcia-Larsen V, Grabenhenrich L, Lack G, Mills C, Wal J-M, Roberts G. Modifying the infant's diet to prevent food allergy. Arch Dis Child 2017; 102:179-186.

12. du Toit, G., Tsakok, T., Lack, S. and Lack, G., 2016. Prevention of food allergy. Journal of Allergy and Clinical Immunology 2016; 137(4), 998-1010.

13. Department of Health and Social Security. Present-Day Practice in Infant Feeding. London: HMSO, 1980. Report on Health and Social Subjects:20.

14. Pipes P.L (1981) Nutrition in Infancy and Childhood. Chapter 7 Infant feeding and nutrition. Pub The C.V.Mosby Company

15. World Health Organisation. Infant and Young Child Feeding. Geneva 2009.

https://www.ncbi.nlm.nih.gov/books/NBK148965/ (last accessed $13^{\text {th }}$ January 2019)

This article is protected by copyright. All rights reserved 
16 Natsume, O., Kabashima, S., Nakazato, J., Yamamoto-Hanada, K., Narita, M., Kondo, M., et al. Two-step egg introduction for prevention of egg allergy in high-risk infants with eczema (PETIT): a randomised, double-blind, placebo-controlled trial. The Lancet 2017; 389: 276-286.

17 Feeney M, Du Toit G, Roberts G, Sayre PH, Lawson K, Bahnson HT, et al. Impact of peanut consumption in The LEAP Study: feasibility, growth and nutrition. J Allergy Clin Immunol 2016; 138: 1108-1118.

18. Pimpin L, Jebb S, Johnson L, Wardle J, Ambrosini G Dietary Protein intake is associated with body mass index and weight up to 5 years of age in a prospective cohort of twins. Am $\mathrm{J}$ Clin Nutr 2016;103:389-97

19. K, Grimshaw K, Oliver E, Roberts G, Arshad SH, Dean T, et al. Taste preference, food neophobia and nutritional intake in children consuming a cows' milk exclusion diet: a prospective study. J Hum Nut Diet 2016; 29: 786-796.

20. Fewtrell, M., Bronsky, J., Campoy, C., Domellöf, M., Embleton, N., Mis, N. F. et al. Complementary Feeding: A Position Paper by the European Society for Paediatric Gastroenterology, Hepatology, and Nutrition (ESPGHAN) Committee on Nutrition. Journal of Pediatric Gastroenterology and Nutrition 2017; 64(1), 119-132.

21. Department of Health and Social Security. Present-Day Practice in Infant Feeding. London: HMSO, 1974. Report on Health and Social Subjects:9.

22 United Kingdom Infant Feeding Study 2010 Consolidated results. https://digital.nhs.uk/dataand-information/publications/statistical/infant-feeding-survey/infant-feeding-survey-uk-2010 (Last accessed 13th January 2019).

23 Office of Population Censuses and Surveys (OPCS). Infant feeding Report 1975.

24. Nicolai A. Lund-Blix, Stine Dydensborg Sander, Ketil Størdal, Anne-Marie Nybo Andersen, Kjersti S. Rønningen, Geir Joner, et al. Infant Feeding and Risk of Type 1 Diabetes in Two Large Scandinavian Birth Cohorts. Diabetes Care 2017;40:920-927.

25 https://www.sign.ac.uk/search-filters.html, last accessed $13^{\text {th }}$ January 2019.

26. Palmer, D. J., Metcalfe, J., Makrides, M., Gold, M. S., Quinn, P., West, C. E.,et al. Early regular egg exposure in infants with eczema: a randomized controlled trial. Journal of Allergy and Clinical Immunology 2013; 132(2), 387-392. 
27. Palmer, D. J., Sullivan, T. R., Gold, M. S., Prescott, S. L. \& Makrides, M. Randomized controlled trial of early regular egg intake to prevent egg allergy. J Allergy Clin Immunol 2017; 139: 1600-1607.

28. Tan, J. W. L., Valerio, C., Barnes, E. H., Turner, P. J., Van Asperen, P. A., Kakakios, A. M., et al. A randomized trial of egg introduction from 4 months of age in infants at risk for egg allergy. $J$ Allergy Clin Immunol 2017; 139: 1621-1628.

29. Bellach, J., Schwarz, V., Ahrens, B., Trendelenburg, V., Aksünger, Ö., Kalb, B. et al. Randomized placebo-controlled trial of hen's egg consumption for primary prevention in infants. $J$ Allergy Clin Immunol 2017; 139: 1591-1599.

30. Du Toit, G., Roberts, G., Sayre, P. H., Bahnson, H. T., Radulovic, S., Santos, A. F., et al.. Randomized trial of peanut consumption in infants at risk for peanut allergy. N Engl J Med 2015, 2015(372), 803-813.

31 Du Toit, G., Sayre, P. H., Roberts, G., Sever, M. L., Lawson, K., Bahnson, H. T., et al.. Effect of avoidance on peanut allergy after early peanut consumption. New England Journal of Medicine 2016; 374(15), 1435-1443.

32.Perkin, M. R., Logan, K., Tseng, A., Raji, B., Ayis, S., Peacock, J., et al. Randomized trial of introduction of allergenic foods in breast-fed infants. New England Journal of Medicine 2016, 374(18), 1733-1743.

33. Preventing Atopic Dermatitis and ALLergies in Children (PreventADALL). https://clinicaltrials.gov/ct2/show/NCT02449850 (last accessed 13th January 2019).

34. Prevention of peanut allergy by early consumption - a prospective study (PEAP) http://apps.who.int/trialsearch/Trial2.aspx?TrialID=DRKS00005487.

35. Tsakok, T., Marrs, T., Mohsin, M., Baron, S., du Toit, G., Till, S. and Flohr, C., 2016. Does atopic dermatitis cause food allergy? A systematic review. Journal of Allergy and Clinical Immunology, 137(4), pp.1071-1078.

36. Ierodiakonou, D., Garcia-Larsen, V., Logan, A., Groome, A., Cunha, S., Chivinge, J. et al. Timing of allergenic food introduction to the infant diet and risk of allergic or autoimmune disease: a systematic review and meta-analysis. JAMA 2016; 316(11), 1181-1192.

37. Roberts, G. Another step towards prevention of food allergy. The Lancet 2017; 389: 230-231.

38. Kramer MS, Kakuma R. Optimal duration of exclusive breastfeeding. Cochrane Database Syst Rev 2012;(8):CD003517. 
39. Tham EH, Shek LP, Van Bever HP, et al. Early introduction of allergenic foods for the prevention of food allergy from an Asian perspective-An Asia Pacific Association of Pediatric Allergy, Respirology \& Immunology (APAPARI) consensus statement. Pediatr Allergy Immunol. 2017;00:1-10.

40. Australasian Society of Clinical Immunology and Allergy. Infant Feeding and Allergy $\begin{array}{llll}\text { Prevention } & \text { in } & \text { (Position } & \text { Statement). }\end{array}$ www.allergy.org.au/images/pcc/ASCIA_Guidelines_infant_feeding_and_allergy_prevention.pdf. Accessed Jan 2019.

41. Fleischer, DM, Sicherer S, Greenhawt M, Campbell D, Chan E, Muraro A, et al. Consensus Communication on Early Peanut Introduction and the Prevention of Peanut Allergy in High-risk Infants. J Allergy Clin Immnol 2015; 136: 258-261.

42. British Society of Allergy and Clinical Immunology. Infant feeding and allergy prevention 2018 https://www.bsaci.org/pdf/Infant-feeding-and-allergy-prevention-PARENTS-FINAL-booklet.pdf. Accessed Jan 2019

43. Turner PJ, Feeney M, Meyer R, Perkin MR, Fox AT. Implementing primary prevention of food allergy in infants: New BSACI guidance published. Clin Exp Allergy 2018;48: 912-5.

44. Togias, A., Cooper, S. F., Acebal, M. L., Assa'ad, A., Baker, J. R., Beck, L. A., ... \& Fleischer, D. M. (2017). Addendum guidelines for the prevention of peanut allergy in the United States. Pediatric Dermatology, 34(1), 5-12. 